\title{
Optimization of Strategic Planning Organization in the Framework of Achievement Objectives of Education
}

\author{
Muhammad Ropianto \\ Sekolah Tinggi Teknik Ibnu Sina Batam \\ Indonesia
}

\author{
Kasman Rukun \\ Universitas Negeri Padang \\ Padang, Indonesia
}

\author{
Hardianto \\ Universitas Pasir Pengaraian Riau \\ Kepulauan Riau, Indonesia
}

\author{
B. Herawan Hayadi \\ Universitas Pasir Pengairan \\ Kepulauan Riau, Indonesia
}

\author{
Mesterjon \\ Universitas Dehasen Bengkulu \\ Bengkulu, Indonesia \\ Feri Hari Utami \\ Universitas Dehasen Bengkulu \\ Bengkulu, Indonesia
}

Oriza Candra

Universitas Negri Padang

Padang, Indonesia

\begin{abstract}
Strategic planning in several educational organizations often do not become a serious concern the education managers. Strategic planning is only made as of administrative requirements without used as guidance in implementing educational organizations. The organization is only driven by intuition and experience of leadership. Moreover, in manufacturing, the strategic plan has not been drawn up based on a thorough analysis of the organization. The achievement of organizational goals effectively and efficiently can only be done in the presence of a solid strategic planning. In the preparation of the strategic plan can be made by taking into account the internal and external environment organization, strategy formulation, strategy implementation and evaluation of strategies. Optimizing the role of a strategic plan can be done by increasing the commitment of members of the organization and the proper use of transformational leadership.
\end{abstract}

Keywords-optimization; strategic planning; objectives; organization of education

\section{INTRODUCTION}

The development of science and technology requires an organization innovation to remain in existence in the face of global challenges. Changes made did not guarantee an improvement, but the circumstances that have occurred as well as the state does not guarantee the best that can be achieved organization. Therefore, organizations need to innovate by taking into account internal and external conditions of the organization to be more and more accepted by the public or customers.

One of the changes that can be done is to optimize the organization's strategic planning role of an organization especially in educational organizations. Strategic planning is very important in education. Results of research [1] argues that "The importance of good strategic planning is a
Recognized throughout higher education." Not only in institutions of higher education, but also every institution needs to be optimized, strategic planning role.

An educational institution is a place that is designed specifically for the implementation of teaching. [2] defines education as all efforts of adults in association with the kids to lead the physical and spiritual development toward maturity. The importance of teaching for children's development, it needs to be managed better, an educational institution. Improved management of educational institutions can be done by optimizing the strategic planning for achieving the vision and mission of the institution.

The same strategy if used continuously will someday fail. Internal and external environmental changes make the organization had to use formula or new strategies in order to cope with changes in the environment. [3] argues that companies that continue to use previously successful strategy, in the end, and certainly fall victim to its competitors. Likewise, in educational institutions, always takes the right strategy bearing in consideration the internal and external environment.

Today it appears that strategic planning has not been implemented properly by most educational institutions. Implementation wheel intuition educational organizations tend to follow the leader. Strategic plans are made only as of administrative requirements that are rarely followed in conducting educational institutions. So also in the making that does not actually pay attention to the educational institutions.

By seeing this, the writer tries to provide input in the form of the idea of the importance of strategic planning to optimize the achievement of organizational goals of education. With the 
expected strategic planning purposes educational institutions can be achieved more effectively and efficiently.

\section{RESEARCH METHOD}

This research used literature study to determine indicators in evaluating the student's comprehension. The subject of this study is the literature related to visualization, comprehension, and the importance of an evaluation framework.

\section{RESULT AND DISCUSS}

\section{A. Making an Effective Strategic Plan}

As described in the previous section, that strategic planning is something very important in educational organizations. Moreover, before discussing and developing strategic plans in education organization, needs be presented educational planning stages.

Educational organizations in making strategic plans must consider the national education plan. It should create a strategic plan that supports the achievement of national education goals. The strategic plan drawn up by taking into account internal and external environment of the organization.

Based on the above opinion, the authors look at the most important step in making strategic planning is the ability planners viewed as objectively as possible the strengths, weaknesses, opportunities and threats of the organization. It is better known as a SWOT analysis. If the strengths, weaknesses, opportunities and threats can be described properly, it will be easier to make the strategies used to maximize the strengths and minimize the weaknesses in seize opportunities and overcome the threat.

The internal factors may be viewed on the strengths and weaknesses of the organization. [3] suggests "business definition in the sense of what they are able to do can be a strong basis for making strategy than the definition based on what needs to be met by the business". Their opinion illustrates that the ability to optimize the power that would be more successful in preparing a plan compare to see what must be owned / worked.

Analysis of the internal environment [2] is carefulness and identification of the condition of internal organization, regarding the organization, operating costs, organizational effectiveness, human resources, facilities and infrastructure and the funds available. Scrutiny carried out by grouping on the things that is a strength or weakness organization in order to realize the goals and objectives.

As planners, managers are required able to correctly identify the strengths of the organization and the weaknesses that exist in the organization. In most educational organization that is large enough, the planners are less able to see the weakness of the organization, because it is affected by the strength of the organization. At this stage, planners can write as many strengths and weaknesses of the organization.

Analysis of the external environment [4] is carefulness and identification of environmental conditions outside the organization that may consist of the economic environment, technological, social, cultural, political, ecological and security. This scrutiny will yield an indication of the opportunities and threats organizations in realizing the goals and objectives of the organization.

To make strategic planning is generally done with the identification phase of the organization, to plan a strategy, execute strategy has been set and evaluate strategies. Wheelen and Hunger presents a strategic management model with four main steps, namely environmental scanning, strategy formulation, strategy implementation, and evaluation and control [3]. While David made a strategic management model by dividing into strategy formulation, strategy implementation and evaluation [5].

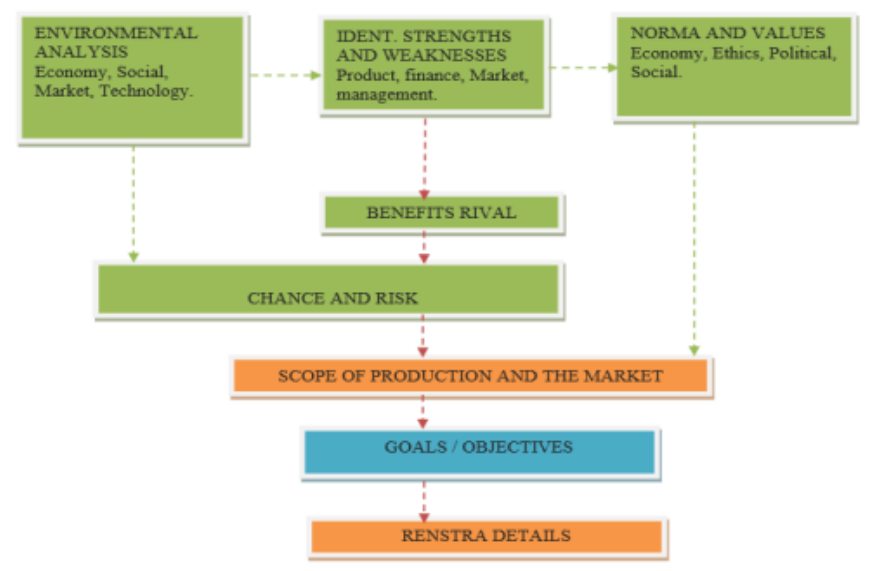

Fig. 1. Strategic planning process

\section{B. Optimization of Strategic Planning in the Context of Educational Achievement Organization}

Seeing the importance of strategic planning in the educational attainment of organizational goals, the strategic plan should be designed properly. The basic principle of a plan is to be able to be implemented.

In general, create a plan much easier than implementing the plan. Strategy has been prepared well, at the time of implementing it sometimes encounter obstacles that are different from the original prediction. [6] suggests implementing a strategy will be more difficult than formulating strategy.

The main problem in the implementation of the strategy may be operating problems execution of strategy and human resources issues. Implementation of operating problems are often caused by lack of thorough planners collect data in view of the strengths, weaknesses, opportunities and threats facing the organization owned and. Planners are too confident with the strength of weakness is often underestimated. Likewise, planners are excited to see the opportunities precisely to disregard the threat. Another problem that can occur is too afraid of the weaknesses that cannot optimize the power and too frightened by the threat that failed to see an opportunity.

Human resources issues can be identified from quantity and quality of its human resources. Organizations do not need to have enough human resources that many but not productive, 
better resources are sufficient and productive. To make a good strategic plan need considerable experience of the planners.

The strategic plan has been prepared needs to be evaluated before they are implemented. Evaluation of strategic plans before they are implemented is useful to look back whether plans have been drawn up can be applied immediately with regard to the situation and available resources. This condition is also known as checking the last plan.

Johnson noted that to evaluate a strategy can be seen from the four criteria, namely consistency, suitability, feasibility and superiority [7]. A plan could be executed if they are consistent, still in accordance with the needs of the external environment, is still eligible for the attainment of the objectives and still have an edge, then the plan is still relevant to be forwarded. Conversely, if the circumstances have changed, such as the strength of the organization is getting stronger, the smaller weaknesses, opportunities and threats the greater the less, it is necessary to re-plan or modification of the plan. Here is presented Figure framework strategy evaluation.

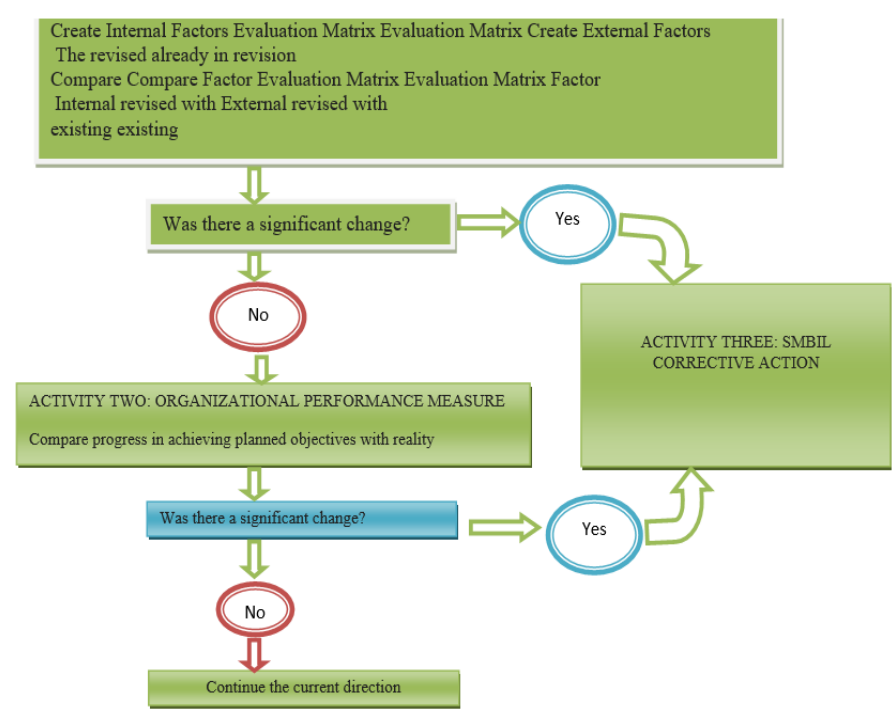

Fig. 2. Strategic evaluation framework

\section{CONCLUSION}

Based on the above discussion, it can be concluded as follows: 1) Developing strategic plans in education organization begins by looking at the strengths and weaknesses of the organization and the opportunities and threats that will be faced by the organization, after the formulation of the strategy, execution implementation and evaluation strategies, and 2) Optimizing the organization's strategic planning in education is done by increasing the commitment of the entire academic community, especially top managers, making the idea of the plan as a good currency, troubleshooting and management structure proper use of transformational leadership.

\section{References}

[1] N.-U.-A. Beg and A. Gupta, 'STRATEGIC PLANNING FOR GOVERNANCE IN HIGHER EDUCATION SYSTEM: A CONCEPTUAL APPROACH', Int. Mon. Ref. J. Res. Manag. Technol., vol. 3, no. 2, pp. 32-39, 2014.

[2] E. M. Hanson, Educational administration and organizational behavior. ERIC, 1996.

[3] T. L. Wheelen and J. D. Hunger, Concepts in strategic management and business policy. Pearson Education India, 2011.

[4] J. A. Okumbe, Educational Management: Theory and Practice. ERIC, 1998.

[5] F. R. David, Strategic management: concepts. Recording for the Blind \& Dyslexic, 2003

[6] R. A. Noe, J. R. Hollenbeck, B. Gerhart, and P. M. Wright, 'Human resource management: Gaining a competitive advantage', 2006

[7] D. Johnson, 'Research methods in educational management', 1995. 